\title{
Job Satisfaction and Narimo Ing Pandum Attitudes: A Mixed Method Study in Indonesia
}

\author{
Tri Murwaningsih ${ }^{1 *}$, Nur Rahmi Akbarini², Muna Fauziah ${ }^{3}$ (iD \\ ${ }^{1,2}$ Faculty of Teacher Training and Education, Universitas Sebelas Maret, Surakarta, Indonesia \\ ${ }^{3}$ Faculty of Tarbiyah, Institut Agama Islam Nahdlatul Ulama Kebumen, Kebumen, Indonesia \\ *Corresponding author: murwaningsih_tri@staff.uns.ac.id
}

\begin{abstract}
Institutions can use customer satisfaction to build loyalty and success in terms of how the agency operates. This study aims to examine the effect of job satisfaction on teacher attitudes and analyze the factors of teacher job satisfaction and the philosophy of Narimo ing Pandum. This research uses a mixed research method. One hundred teachers followed this study. The data were collected by using interview and questionnaire techniques. Data analysis was carried out using simple linear regression analysis and interactive analysis (data reduction, data presentation, and levers/conclusions). The findings of this study reveal a significant effect of job satisfaction on the attitudes of teachers of SMK Narimo ing Pandum. The highest factor of teacher job satisfaction is the support of colleagues $(20.27 \%)$ and the lowest factor is the work itself $(13.77 \%)$. Meanwhile, the highest proportion of Narimo ing Pandum attitude is honest and sincere (22.28\%) and the lowest percentage is gratitude (13.17\%). This finding contributes that school principals need to give serious attention to job satisfaction and attitudes towards Narimo ing Pandum by optimizing what teachers need in teaching. It is hoped that teachers can apply the principles of Narimo ing Pandum.
\end{abstract}

Keywords: Job Satisfaction, Narimo Ing Pandum, Vocational High School Teachers

$\begin{array}{ll}\text { History: } & \\ \text { Received } & \text { : August 03, } 2021 \\ \text { Revised } & \text { : August 10, } 2021 \\ \text { Accepted } & \text { : September 27, } 2021 \\ \text { Published } & \text { : October 25, } 2021\end{array}$

\section{INTRODUCTION}

Science and technology development creates increasingly fierce and competitive competition for human resources (Ho \& Ismawan Prasetia Devi, 2020; Yilmaz \& Korur, 2021). In competing with other countries, the quality of human resources is increasingly becoming a priority (Indiyaningsih et al., 2020; Wagiran et al., 2019). In this case, teachers play a central role in efforts to make a quality and reliable generation (Bdiwi et al., 2019; Graham et al., 2020). Teachers become professional figures in line with their educational qualifications and experience (Ambussaidi \& Yang, 2019; Bdiwi et al., 2019; Graham et al., 2020; Murati, 2015). In carrying out their duties, teachers are required to optimize their performance and have quality knowledge or skills, have a commitment to students, master all subjects, create suitable teaching methods, assess students with precise measurements, think systematically, and become part of the learning community in professional development (Moskvina, 2015; Sisask et al., 2014; Tanang \& Abu, 2014).

Moreover, teachers' attitudes at work vary widely, from attitudes that seem trivial to those most needed. In Javanese culture, elders often tell everyone to live in peace and inner peace. The message contains Narimo ing Pandum principle. Narimo ing Pandum is defined as the attitude of accepting all gifts without any demands (Ariani \& Pratama, 2017; Santoso et al., 2020). This concept is one of the Javanese philosophies that are popular and still adhered to by the community. Narimo ing Pandum concept has a relationship between giving and receiving. For Javanese people, someone is always required to give unconditionally, always be grateful, honest, and sincere (Wijayanti, 2018). 
Narimo ing Pandum concept is related to the attitude that teachers should have in this globalization era. Teachers should be able to apply the meaning and character of Narimo ing Pandum's attitude because this attitude is part of Indonesian society's culture. Teachers must have an honest and sincere attitude in teaching (Arievitch, 2020; Huang et al., 2020). Not only that, but teachers also have to accept all assignments and challenges, be confident, have a positive attitude, and be able to control themselves emotionally (Russo et al., 2020; Selvaraj et al., 2021). These duties and challenges are, of course, related to their profession as a teacher. Teacher attitudes will result in better classroom action, shape student behaviour and achievement, and influence teacher feelings and thoughts in decision making (Kin et al., 2018; Mellom et al., 2018; Russo et al., 2020).

However, the facts on the field report that the problems in the world of education are very complex. In addition to these data, it was also found that certified teachers at the vocational high school level had low performance. It was evidenced by the 2020 Teacher Competency Test (TCT) data. The data analysis results showed an average National TCT score of 53.02, while the government targeted an average score of 55. On the other hand, the average professional score was 54.77 and the average pedagogic competency score only reached 48.94. The performance results were very disappointing. Besides, other empirical data has proven that there were still very few vocational high school teachers who had been certified since 2019. The data is shown in the following figure.

The Ministry of Education and Culture noted that the number of certified teachers in Indonesia had not reached 50\%. The highest percentage of certified teachers was achieved by junior high school at $48.44 \%$, while the smallest percentage was obtained by vocational high school level only at $28.94 \%$. Other supporting data regarding attendance data for professionally certified teachers for six consecutive periods uncovers the following results (Ministry of Education and Culture, 2019).

Table 1. Recapitulation of certified teacher attendance in 2009-2014

\begin{tabular}{ccccc}
\hline Period & $\begin{array}{c}\text { Number of teachers who } \\
\text { have been certified }\end{array}$ & Alpha & $\begin{array}{c}\text { Percentage of } \\
\text { absences }\end{array}$ & $\begin{array}{c}\text { Percentage of } \\
\text { attendance }\end{array}$ \\
\hline $2009 / 2010$ & 25 teachers & 3 & $12 \%$ & $88 \%$ \\
$2010 / 2011$ & 36 teachers & 2 & $5.6 \%$ & $94.4 \%$ \\
$2011 / 2012$ & 41 teachers & 3 & $7.3 \%$ & $92.7 \%$ \\
$2012 / 2013$ & 46 teachers & 4 & $8.6 \%$ & $91.4 \%$ \\
$2013 / 2014$ & 50 teachers & 2 & $4.0 \%$ & $96.0 \%$ \\
$2014 / 2015$ & 53 teachers & 5 & $9.4 \%$ & $90.6 \%$ \\
\hline
\end{tabular}

From Table 1 above, it is clear that some certified teachers did not attend school on purpose every year. Therefore, it can be interpreted that among some of these teachers, teachers still had low discipline, integrity, and responsibility attitudes. Even though the number was less than $10 \%$, teacher absence from school would adversely affect the climate and overall school performance. It causes the principal to emphasize that all teachers improve their performance and attitudes while carrying out their profession. Based on the many problems regarding teacher attitudes, it is necessary to test job satisfaction on Narimo ing Pandum's attitude and examine each aspect of teacher job satisfaction and Narimo ing Pandum's attitude. Job satisfaction is a general attitude and feeling resulting from the influence of various particular attitudes and feeling such as factors in work, adjustment, acceptance, and social relationships (Hanna et al., 2017; Hidayat et al., 2020; Yuliandi \& Tahir, 2019). Further, teacher job satisfaction is primarily determined by several things, such as the principal's leadership style, the relationship between teachers and students and colleagues, appreciation, work environment, supportive colleagues, challenging work, and 
interaction of social needs (Chamundeswari, 2013; Dorozynska, 2016; Olcum \& Titrek, 2015).

A similar study, which resulted in the finding that teacher satisfaction was caused by monetary and non-monetary incentives (Nyamubi, 2017). The findings of previous research also stated that job satisfaction affected employees' careers with minimal results (Lee, Yang, \& Li, 2017). Academics in Spain provided different productivity in realizing their careers (Albert, Davia, \& Legazpe, 2018). Job satisfaction was negatively correlated with employee mental health (Allan, Dexter, Kinsey, \& Parker, 2018). Previous findings have indeed reviewed something similar to this study. However, this research has its uniqueness, where the researchers employed a mixed-method approach so that the research results are comprehensive. Then, there has not been found a similar study conducted in Indonesia as a developing country, which requires intensive testing and in-depth analysis of teacher performance satisfaction and Narimo ing Pandum attitudes. Although some findings share some similarities, they are still rarely conducted and directed at vocational secondary school teachers. Most previous researchers targeted their research at university students or students at a level below them. Meanwhile, vocational high school teachers need to know the extent to which job satisfaction affects their attitude of accepting their assignments and the factors of job satisfaction and Narimo ing Pandum attitude as Indonesian culture. Thus, the factors of the emergence of vocational high school teachers' job satisfaction and Narimo ing Pandum attitude are also the topic of this research review so that the data obtained are complex.

The purpose of this research is to analyze the job satisfaction and attitude of Nrimo Ing Pandum. Through many considerations, both the problems in the field and the differences between this study and previous research, this study is interesting to be reviewed in a mixed-method regarding teacher job satisfaction and Narimo ing Pandum attitude of vocational high school teachers in Solo Raya, Indonesia.

\section{METHODS}

This study used mixed-method research. The researchers' objective in using the mixed method was to combine the two approaches at once, expand, and strengthen the research conclusions. As for the design employed, it was an explanatory sequential design. This design was carried out by collecting quantitative and qualitative data at different times. This study's population was teachers in Office Automation and Governance (OAG) expertise in the Solo Raya area, Indonesia. Meanwhile, the sampling technique in this study was purposive sampling. Thus, this research's sample consisted of 100 teachers who were already civil servants and certified. This region comprises several cities and regencies in Central Java, Indonesia. At least nine public vocational high schools were this research's location.

This study uses an explanatory sequential design. In this design, there are several steps taken by the researchers. First, the researchers formulate the problem. Second, researchers seek and create theoretical foundations and hypotheses. Third, researchers collect and analyse quantitative data. Fourth, the researchers tested the hypothesis. Fifth, researchers continue research with qualitative methods by determining the source of research data. Sixth, the researchers collect and analyse qualitative data. Seventh, researchers analysed quantitative and qualitative data. Finally, the researchers make conclusions and suggestions.

Data collection was carried out in two ways: quantitatively and qualitatively. In a quantitative approach, a questionnaire was utilized as a data collection tool. The questionnaire technique was conducted by spreading out a questionnaire sheet consisting of 15 statements. The use of a questionnaire applied a Likert scale with four answer choices: strongly agree, agree, disagree, and strongly disagree. The questionnaire statement was divided into two attitude statements: supportive and unsupportive statements. Meanwhile, 
interviews were employed to collect data on a qualitative approach. Interviews were conducted with interview sheets. Interviews were addressed to nine teachers. Each school was represented by one teacher. This data collection method was chosen, hoping that the researcher would obtain information relevant to the studied problem and had a high accuracy degree.

Data analysis was carried out in two ways: quantitative and qualitative. Quantitative data analysis techniques were assisted by SPSS version 19 program. The calculations focused on simple linear regression analysis. This analysis was conducted to determine the magnitude of the job satisfaction's effect on Narimo ing Pandum attitude. Apart from regression analysis, the researchers also tested the research hypothesis. The test used was t-test. This test was utilized to show how far one explanatory variable's influence in estimating the dependent variable. Meanwhile, qualitative data analysis followed the interactive analysis model. Activities in the analysis include data reduction, data presentation, and drawing conclusions and verification.

\section{RESULTS AND DISCUSSION}

\section{Results}

The quantitative analysis results generated three data: simple linear regression analysis, the correlation and determination test coefficients, and the t-test. The correlation/relationship (R) value was 0.396. From this output, the coefficient of determination ( $\mathrm{R}$ square) was 0.157 . It implies that the effect of the independent variable (job satisfaction) on the dependent variable (Narimo ing Pandum attitude) was 15.7\%. From this output, it is known that the $F_{\text {calculated }}$ was 18,271 , with a significance level of $0.000<0.05$. Thus, the regression model could be used to predict job satisfaction variables. In other words, there was an effect of job satisfaction on Narimo ing Pandum attitudes. The constant value (a) was 15,702 , while the job satisfaction value (b/regression coefficient) was 0.380 , so the regression equation can be written: $\mathrm{Y}=15.702+0.380 \mathrm{X}$. From this equation, it can be translated that a constant value of 15,702 means that the constant value of Narimo ing Pandum attitude variable was 15,702 . Then, the $\mathrm{X}$ regression coefficient of 0.380 denotes that for every $1 \%$ increase in job satisfaction, Narimo ing Pandum attitude value increases by 0.380. The regression coefficient was positive so that the direction of the job satisfaction variable's influence on Narimo ing Pandum attitude was also positive.

Based on the significance value, it is known that the coefficient table showed a significance value of $0.000<0.05$, and at the $t$-value, it is known that the $t_{\text {calculated }}$ value of 4.274> $\mathrm{t}_{\text {table }}$ of 1.984. Thus, it can be concluded that the job satisfaction variable had a significant effect on Narimo ing Pandum attitude. Teacher job satisfaction is essential to pay attention to because it can maintain the fulfilment of the teacher's quality performance. Besides affecting itself, job satisfaction also affects students. The results of distributing questionnaires conducted to vocational high school teachers majoring in Office Management Automation in Solo Raya indicate six factors, each of them having its proportion in increasing job satisfaction. These factors included the job itself, rewards, promotion opportunities, and support from co-workers, supervision, and working conditions. The results are presented in the following table.

The highest percentage to support teacher job satisfaction was the co-worker support factor of $20.27 \%$, while the lowest percentage was the work factor itself of $13.77 \%$. The questionnaire results were then correlated with the interview results with several teachers. The work factor itself was so low because teachers had not felt comfortable with their work so far. Moreover, teachers still received quite a lot of workload. Teachers hope that they can do work that provides opportunities to use their skills and abilities, opening up opportunities 
for them to learn and accept responsibility to see their assignments as interesting jobs. However, the work currently being carried out has not led to their expectations so far. Thus, it is hoped that the work suitability with the teachers' skills and abilities can encourage them to produce good performance later. Furthermore, the factor of co-worker support was ranked first among five other factors. From the interview results, it was found that the teachers had found good colleagues, provided mutual support, assistance, or suggestions so that they felt that their work was enjoyable. The teacher also said that good relations with colleagues would be meaningful if the work required teamwork. Close relationships with colleagues will affect the quality of work produced. Groups with a high cohesiveness level will make teachers feel satisfied in their groups. Due to reduced tension and anxiety in groups and individuals in the group, they adjust to working pressure.

The analysis related to Narimo ing Pandum attitude became the dependent variable in this study. Based on the questionnaire distribution results, the data revealed that six things were studied: accepting fate, being grateful, accepting existing obligations, being selfless, honest and sincere, and being light in doing work. The highest category was obtained in the honest and sincere aspects $(22.28 \%)$, while the lowest was obtained in the gratitude indicator $(13.17 \%)$. Meanwhile, after being honest and sincere, the following sequences were light in doing work, selflessness, accepting existing obligations, accepting fate, and being grateful. The interview results with teachers reported that honesty and sincerity should always be applied in teaching. Teachers are synonymous with the process of teaching and dealing with students, so they must have an honest and sincere attitude. Both attitudes will make the work lighter. Sincerity also means that the teacher teaches without expecting anything in return. It is because teachers have promised to maintain their profession and must accept all obligations in their duties as teachers.

\section{Discussion}

The results showed that there was a significant effect of job satisfaction on Narimo ing Pandum attitude. This influence was caused by several related factors of job satisfaction and Narimo ing Pandum. This finding is in line with previous studies that satisfaction affected teacher work attitudes (Lee et al., 2017). After all, the condition of job satisfaction had a significant impact on leadership and teacher trust, how to work, happiness at work, and employee satisfaction (Andargie \& Azar, 2019; Herman \& Didin, 2020; Liu et al., 2020). This study is also findings, which concluded a relationship between teacher attitudes and job satisfaction (Saiti \& Papadopoulos, 2015; Türkoğlu et al., 2017). Another study has also revealed that teacher attitudes were an intermediate variable between school conditions and job satisfaction (Katsantonis, 2019; Toropova et al., 2021).

Nevertheless, this study's findings are also contrary to previous studies that experience and acceptance at work were not positively correlated with job satisfaction (Shaukat, Vishnumolakala, \& Al Bustami, 2019). This difference in results could occur due to the population's conditions or environment studied. Previous research was conducted in Turkey, while this research was carried out in Indonesia. Demographically and rationally, the income earned in Indonesia is different from Turkey. From this study's results, it was uncovered that job satisfaction and Narimo ing Pandum each was divided into six factors. Factors affecting job satisfaction were the work itself, rewards, promotion opportunities, coworker support, supervision, and working conditions. Meanwhile, Narimo ing Pandum attitude factors consisted of accepting fate, being grateful, accepting existing obligations, being selfless, honest and sincere, and light in doing work.

In the job satisfaction variable, co-workers were one of the factors affecting teacher job satisfaction. Good communication between teachers could increase teacher job satisfaction (Judge et al., 2002; Liu et al., 2020). Moreover, if these colleagues have the same 
attitude, it will create a pleasant and harmonious work atmosphere (Merz \& Roesch, 2011; Perera \& McIlveen, 2017; Saiti \& Papadopoulos, 2015; Skapinaki \& Salamoura, 2020). Communication and harmony will produce a comfortable mood so that the teacher is grateful for these conditions. Another study has also informed a link between the involvement of support from teacher colleagues and job satisfaction (Lent et al., 2016; Türkoğlu et al., 2017).

Moreover, other factors such as rewards, promotion opportunities, supervision, and working conditions are inseparable aspects to produce satisfaction and acceptance of work. As written in the report, factors such as policies, supervision, salary, and work situations affected work and work motivation (Sweeney, 2012). In line with Sweeney's opinion, job satisfaction factors are considered very important for health, capacity, and the school system in general (Bedi et al., 2021; Nyamubi, 2017). The supervision factor becomes urgent because teachers can get support from other co-workers to increase the chances of successful ideas (Mishra et al., 2019; Toropova et al., 2021). Supervision led by the principal is also proven to have a significant relationship with the implementation of teacher empowerment so that teachers are increasingly motivated to create innovations (Cobanoglu, 2021). Unfortunately, other studies' findings refute this study's results, in which teachers perceived supervision in learning as typical (Chapagain, 2021; Yucel \& Minnotte, 2017).

For some people, this satisfaction with the salary provision includes not only the nominal salary obtained, but more to the teachers' satisfaction with payroll administration policies, the existence of various allowance types, and satisfaction with the salary increase levels (Han et al., 2018). Regarding the addition and reduction of salaries, it is under the laws of each country (Daina et al., 2019). Each group has a different salary rate. As reported by previous findings, salary earnings were also influenced by educational qualifications (Brenzel et al., 2014; Hall \& Krueger, 2012). In this case, big or small rewards will help teachers to appreciate better what they get. An attitude of respect will lead to sincerity and accepting the job that the teacher is currently working on.

Regarding job promotion, this study's findings are consistent with previous studies, where promotion is a form of reward that individuals get from their work so that they are willing to give their best performance sincerely and sustainably (Byron \& Khazanchi, 2012; Muzafary et al., 2021). The working condition factor also gives a high enough contribution to teacher job satisfaction. Comfortable working conditions will certainly help the teacher's work lighter. This study's findings align with previous studies that place and work conditions positively affect fairness at work, work stability, acceptance, gratitude, and security at work (Cherniak et al., 2020; Hussain \& Endut, 2018). Employee performance will remain stable, balanced with comfortable working conditions and social dialogue among employees.

Another report produced findings that working conditions were also related to the institutions' quality and facilities to make effective classroom learning practices (Bettini et al., 2016; Kraft \& Papay, 2014). In line with these findings, that teachers who do work in positive environmental conditions make their willingness to teach better and have a gratitude attitude for their work (Jones et al., 2013; Skapinaki \& Salamoura, 2020). Good intentions will be the beginning of the teacher's sincerity in work. Meanwhile, the inconvenience of working conditions negatively impacts the teachers' comfort and effectiveness in learning because almost all teachers feel that their knowledge and skills are based on their learning experiences (Ronfeldt et al., 2013). Thus, no doubt, working conditions are needed and directly affect teacher actions (Bettini et al., 2015, 2016).

Accordingly, each job satisfaction factor had a relationship with Narimo ing Pandum indicator. When the workload, work conditions, rewards, promotion opportunities, supervision, and co-worker support are well fulfilled, every teacher may have the full Narimo ing Pandum attitude. The teacher will have the attitude of accepting assignments and fate (running the profession) to coincide with gratitude and sincerity attitudes. With these 
attitudes, later, the teachers will feel that their work feels light and will create an attitude of accepting everything given. This study has limitations on the narrow focus research established. Another limitation is the difficulty in finding Narimo ing Pandum theory. Therefore, the researchers suggest the next researcher expand the focus of similar research and look for variables with easy-to-find theories. Future researchers can add other variables to obtain broad information, such as testing the effectiveness of job satisfaction and work attitudes on teacher performance.

\section{CONCLUSION}

There was a significant effect of job satisfaction on Narimo ing Pandum attitude. In addition, job satisfaction was influenced by six factors: co-worker support, supervision, job promotion, job conditions, rewards, and the work itself. Meanwhile, Narimo ing Pandum was affected by accepting fate, being grateful, accepting obligations, being selfless, honest and sincere, and light in doing work.

\section{REFERENCES}

Albert, C., Davia, M. A., \& Legazpe, N. (2018). Job satisfaction amongst academics: The role of research productivity. Studies in Higher Education, 43(8), 1362-1377. https://doi.org/10.1080/03075079.2016.1255937.

Allan, B. A., Dexter, C., Kinsey, R., \& Parker, S. (2018). Meaningful work and mental health: Job satisfaction as a moderator. Journal of Mental Health, 27(1), 38-44. https://doi.org/10.1080/09638237.2016.1244718.

Ambussaidi, I., \& Yang, Y.-F. (2019). The Impact of Mathematics Teacher Quality on Student Achievement in Oman and Taiwan. International Journal of Education and Learning, 1(2), 50-62. https://doi.org/10.31763/ijele.v1i2.39.

Andargie, M. S., \& Azar, E. (2019). An applied framework to evaluate the impact of indoor office environmental factors on occupants' comfort and working conditions. Sustainable Cities and Society, 46(January), 101447. https://doi.org/10.1016/j.scs.2019.101447.

Ariani, I., \& Pratama, M. A. (2017). IVF (In Vitro Fertilization) as an ethical choices on ethical perspective of Thomas Aquinas Natural Law. The 6th International Conference on Social Sciences and Humanities, 962-967.

Arievitch, I. M. (2020). The vision of Developmental Teaching and Learning and Bloom's Taxonomy of educational objectives. Learning, Culture and Social Interaction, 25. https://doi.org/10.1016/j.lcsi.2019.01.007.

Bdiwi, R., de Runz, C., Faiz, S., \& Cherif, A. A. (2019). Smart learning environment: Teacher's role in assessing classroom attention. Research in Learning Technology, 27, 1-14. https://doi.org/10.25304/rlt.v27.2072.

Bedi, I. K., Kukemelk, H., \& Bardone, E. (2021). Practices, personal and school factors that influenced school heads' job stress and satisfaction. European Journal of Educational Research, 10(1), 51-62. https://doi.org/10.12973/EU-JER.10.1.51.

Bettini, E. A., Crockett, J., Brownell, M. T., \& Merrill, K. (2016). Relationships between working conditions and special edu- cators' instruction. The Journal of Special Education, 50, 178-190. https://doi.org/10.1177/0022466916644425.

Bettini, E. A., Kimerling, J., Park, Y., \& Murphy, K. (2015). Responsibilities and instructional time: Relationships identified by special educators in self-contained classes for students with emotional and behavioral disabilities. Preventing School Failure, 59, 121-128. https://doi.org/10.1080/1045988X.2013.859561. 
Brenzel, H., Gartner, H., \& Schnabel, C. (2014). Wage bargaining or wage posting? Evidence from the employer's side. Labour Econ, 29, 41-48. https://doi.org/10.1016/j.labeco.2014.05.004.

Byron, K., \& Khazanchi, S. (2012). Rewards and creative performance: A meta-analytic test of theoretically derived hypotheses. Psychological Bulletin, 138(4), 809-830. https://doi.org/10.1037/a0027652.

Chamundeswari, S. (2013). Job satisfaction and performance of school teachers. International Journal of Academic Research in Business and Social Sciences, 3(5), 420-427. https://doi.org/10.11591/ijere.v8i4.20264.

Chapagain, R. B. (2021). Job Satisfaction among Academicians in Nepal: The Influence of Institutional Sector and Demographic. Quantitative Economics and Management Studies, 2(2), 94-104. https://doi.org/10.35877/454ri.qems267.

Cherniak, O., Trishch, R., Kim, N., \& Ratajczak, S. (2020). Quantitative assessment of working conditions in the workplace. Engineering Management in Production and Services, 12(2), 99-106. https://doi.org/10.2478/emj-2020-0014.

Cobanoglu, N. (2021). The relationship between shared leadership, employee empowerment and innovativeness in primary schools: A structural equation modeling. European Journal of Educational Research, 10(1), 327-339. https://doi.org/10.12973/eujer.10.1.327.

Daina, L. G., Sabău, M., Daina, C. M., Neamt, U. C., Tit, D. M., Buhas, C. L., Bungau, C., Aleya, L., Bungau, S., \& Corina, N. (2019). Improving performance of a pharmacy in a Romanian hospital through implementation of an internal management control system. Sci. Total. Environ, 675, 51-61. https://doi.org/10.1016/j.scitotenv.2019.04.231.

Dorozynska, A. (2016). Teacher job satisfaction in primary schools the relation to work environment. Department of Education and Special Education.

Graham, L. J., White, S. L. J., Cologon, K., \& Pianta, R. C. (2020). Do teachers' years of experience make a difference in the quality of teaching? Teaching and Teacher Education, 96, 103190. https://doi.org/10.1016/j.tate.2020.103190.

Hall, R. E., \& Krueger, A. B. (2012). Evidence on the incidence of wage posting, wage bargaining, and on-the-job search. American Economic Journal: Macroeconomics, 4(4), 56-67. https://doi.org/10.1257/mac.4.4.56.

Han, S. W., Borgonovi, F., \& Guerriero, S. (2018). What motivates high school students to want to be teachers? The role of salary, working conditions, and societal evaluations about occupations in a comparative Perspective. American Educational Research Journal, 55(1), 3-39. https://doi.org/10.3102/0002831217729875.

Hanna, B., Kee, K. F., \& Robertson, B. W. (2017). Positive Impacts of Social Media at Work: Job Satisfaction, Job Calling, and Facebook Use among Co-Workers. SHS Web of Conferences, 33(SHS Web 00012. https://doi.org/10.1051/shsconf/20173300012.

Herman, \& Didin, D. (2020). The influence of work motivation, job satisfaction and work discipline on employee performance in the regional secretariat of Maros district. Jurnal Ad'ministrare, 7(1), 1-8. https://doi.org/10.26858/ja.v7i1.14777.

Hidayat, D., Maitimo, V. V. S., \& Suwu, S. E. (2020). Increasing Teachers' Work Engagement Through Servant Leadership, Organizational Culture, and Job Satisfaction. Jurnal Pendidikan Dan Pengajaran, 53(April), 90-100. https://doi.org/10.23887/jpp.v53i1.24911.

Ho, L., \& Ismawan Prasetia Devi. (2020). A New trend in understanding students' interest in learning science: microetnography. Integrated Science Education Journal (ISEJ), 1(2), 62-66. https://doi.org/10.37251/isej.v1i2.72. 
Huang, S. Y., Kuo, Y. H., \& Chen, H. C. (2020). Applying digital escape rooms infused with science teaching in elementary school: Learning performance, learning motivation, and problem-solving ability. Thinking Skills and Creativity, 37(129), 100681. https://doi.org/10.1016/j.tsc.2020.100681.

Hussain, A. H. M. B., \& Endut, N. (2018). Factors influencing working conditions of small enterprises in Sylhet City, Bangladesh. Development in Practice, 28(1), 138-151. https://doi.org/10.1080/09614524.2018.1404008.

Indiyaningsih, K. M. H., Murdyastuti, A., \& Puspitaningtyas, Z. (2020). Efeect of human resource competency, work culture and utilization of information technology to performance of employees. International Journal of Scientific and Technology Research, 9(4), 3636-3641. https://doi.org/10.19184/issrd.v2i1.17468.

Jones, N. D., Youngs, P., \& Frank, K. A. (2013). The role of school-based colleagues in shaping the commitment of novice special and general education teachers. Exceptional Children, 79(3), 365-383. https://doi.org/10.1177/001440291307900303.

Judge, T. A., Eller, D., \& Mount, M. K. (2002). Five-factor model of personality and job satisfaction: A meta-analysis. Journal of Applied Psychology, 87(3), 530-541. https://doi.org/10.1037/0021-9010.87.3.530.

Katsantonis, I. G. (2019). Investigation of the impact of school climate and teachers' selfefficacy on job satisfaction: A cross-cultural approach. European Journal of Investigation in Health, Psychology and Education, 10(1), 119-133. https://doi.org/10.3390/ejihpe10010011.

Kin, T. M., Abdull Kareem, O., Nordin, M. S., \& Wai Bing, K. (2018). Principal change leadership competencies and teacher attitudes toward change: the mediating effects of teacher change beliefs. International Journal of Leadership in Education, 21(4), 427446. https://doi.org/10.1080/13603124.2016.1272719.

Kraft, M. A., \& Papay, J. P. (2014). Can professional environments in schools promote teacher development? Explaining heterogeneity in returns to teaching experience. Educational Evaluation and Policy Analysis, 36, 476-500. https://doi.org/10.3102/0162373713519496.

Lee, X., Yang, B., \& Li, W. (2017). The influence factors of job satisfaction and its relationship with turnover intention: Taking early-career employees as an example. Anales de Psicología, 33(3), 697. https://doi.org/10.6018/analesps.33.3.238551.

Lent, R. W., Taveira, M. do C., Figuera, P., Dorio, I., Gonçalves, F. S., \& Manuela, A. (2016). Test of the social cognitive model of well-being in Spanish College Students. Journal of Carrer Assessment, 25(1), 135-143. https://doi.org/10.1177/1069072716657821.

Liu, Y., Bellibaş, M. Ş., \& Gümüş, S. (2020). The effect of instructional leadership and distributed leadership on teacher self-efficacy and job satisfaction: Mediating roles of supportive school culture and teacher collaboration. Educational Management Administration and Leadership, 1-24. https://doi.org/10.1177/1741143220910438.

Mellom, P. J., Straubhaar, R., Balderas, C., Ariail, M., \& Portes, P. R. (2018). "They come with nothing:" How professional development in a culturally responsive pedagogy shapes teacher attitudes towards Latino/a English language learners. Teaching and Teacher Education, 71, 98-107. https://doi.org/10.1016/j.tate.2017.12.013.

Merz, E. L., \& Roesch, S. C. (2011). A latent profile analysis of the five factor model of personality: Modeling trait interactions. Personality and Individual Differences, 51(8), 915-919. https://doi.org/10.1016/j.paid.2018.12.002.

Ministry of Education and Culture. (2019). Teacher competency test data. Regional Education Accounts.

Mishra, P., Bhatnagar, J., Gupta, R., \& Wadsworth, S. M. (2019). How work-family 
enrichment influence innovative work behavior: Role of psychological capital and supervisory support. Journal of Management and Organization, 25(1), 58-80. https://doi.org/10.1017/jmo.2017.23.

Moskvina, N. (2015). Some methodology approaches to the analysis of personal and professional teachers. Pacific Science Review, 15, 1-10. https://doi.org/10.1016/j.pscr.2015.01.001.

Murati, R. (2015). The Role of the Teacher in the Educational Process. The Online Journal of New Horizon in Education, 5(2), 75-78. https://www.tojned.net/journals/tojned/articles/v05i02/v05i02-09.pdf.

Muzafary, S. S., Ali, I., \& Hussain, M. (2021). Intrinsic rewards and employee creative performance: Moderating effects of job autonomy and proactive personality: A perspective of self-determination theory. International Journal of Innovation, $\begin{array}{llll}\text { Creativity and } & \text { Change, 15(2), }\end{array}$ https://www.tojned.net/journals/tojned/articles/v05i02/v05i02-09.pdf.

Nyamubi, G. J. (2017). Determinants of secondary school teachers' job satisfaction in Tanzania. Education Research International, 2017(1), 1-7. https://doi.org/10.1155/2017/7282614.

Olcum, D., \& Titrek, O. (2015). The effect of school administrators' decision-making styles on teacher job satisfaction. Procedia - Socialand Behavioral Sciences, 197, 19361946. https://doi.org/10.1016/j.sbspro.2015. 07.575.

Perera, H. N., \& McIlveen, P. (2017). Profiles of career adaptivity and their relations with adaptability, adapting, and adaptation. Journal of Vocational Behavior, 98, 70-84. https://doi.org/10.1016/j.jvb.2016.10.001.

Ronfeldt, M., Loeb, S., \& Wyckoff, J. (2013). How teacher turn- over harms student achievement. American Educational Research Journal, 50, 4-36. https://doi.org/10.3102/0002831212463813.

Russo, J., Bobis, J., Sullivan, P., Downton, A., Livy, S., McCormick, M., \& Hughes, S. (2020). Exploring the relationship between teacher enjoyment of mathematics, their attitudes towards student struggle and instructional time amongst early years primary teachers. Teaching and Teacher Education, 88(102983), 1-9. https://doi.org/10.1016/j.tate.2019.102983.

Saiti, A., \& Papadopoulos, Y. (2015). School teachers' job satisfaction and personal characteristics: A quantitative research study in Greece. International Journal of Educational Management, 29(1), 73-97. https://doi.org/10.1108/ijem-05-2013-0081.

Santoso, R. A., Salim, U., Sumiati, \& Andarwati. (2020). The meaning of profit with a cultural perspective on the traditional market with pancawara cycle traders. International Journal of Innovation, Creativity and Change, 13(9), 1484-1504.

Selvaraj, A., Radhin, V., KA, N., Benson, N., \& Mathew, A. J. (2021). Effect of pandemic based online education on teaching and learning system. International Journal of Educational Development, 85(May), 102444. https://doi.org/10.1016/j.ijedudev.2021.102444.

Shaukat, S., Vishnumolakala, V. R., \& Al Bustami, G. (2019). The impact of teachers' characteristics on their self-efficacy and job satisfaction: a perspective from teachers engaging students with disabilities. Journal of Research in Special Educational Needs, 19(1), 68-76. https://doi.org/10.1111/1471-3802.12425.

Sisask, M., Apter, A., Balazs, J., Balint, M., Bobes, J., Brunner, R., \& Wasserman, D. (2014). Teacher satisfaction with school and psychological well-being affects their readiness to help children with mental health problems. Health Education Journa, 73(4), 382393. https://doi.org/10.1177/00178969134 85742.

Skapinaki, A., \& Salamoura, M. (2020). Investigating primary school quality using teachers' 
self-efficacy and satisfaction. Journal of Tourism, Heritage \& Services Marketing, 6(1), 17-20. https://doi.org/10.5281/zenodo.3603340.

Sweeney, P. D. (2012). Distributive justice and pay satisfaction: A field test of an equity theory prediction. Journal of Business and Psychology, 4(3), 329-341. https://doi.org/10.1007/BF01125243.

Tanang, H., \& Abu, B. (2014). Teacher professionalism and professional development practices In South Sulawesi, Indonesia. Journal of Curriculum and Teaching, 3(3), 25-42. https://doi.org/10.5430/jct.v3n2p25.

Toropova, A., Myrberg, E., \& Johansson, S. (2021). Teacher job satisfaction: the importance of school working conditions and teacher characteristics. Educational Review, 73(1), 71-97. https://doi.org/10.1080/00131911.2019.1705247.

Türkoğlu, M. E., Cansoy, R., \& Parlar, H. (2017). Examining relationship between teachers' self-efficacy and job satisfaction. Universal Journal of Educational Research, 5(5), 765-772. https://doi.org/10.13189/ujer.2017.050509.

Wagiran, Pardjono, Suyanto, W., Sofyan, H., Soenarto, S., \& Yudantoko, A. (2019). Competencies of Future Vocational Teachers: Perspective of in-Service Teachers and Educational Experts. Cakrawala Pendidikan, 38(2), 388-400. https://doi.org/10.21831/cp.v38i2.25393.

Wijayanti, A. (2018). Implementation of Javanese local wisdom principles as alternative solution for non-litigation legal aid model for marginal community. In Proceedings Ofthe Annual Conference on Social Sciences and Humanities (ANCOSH, April, 419424. https://doi.org/10.5220/000741420.

Yilmaz, E., \& Korur, F. (2021). The Effects of an Online Teaching Material Integrated Methods on Students' Science Achievement, Attitude and Retention. International Journal of Technology in Education, 4(1). https://doi.org/https://doi.org/10.46328/ijte.79.

Yucel, D., \& Minnotte, K. L. (2017). Workplace support and life satisfaction: The mediating roles of work-to-family conflict and mental health. Applied Research in Quality of Life, 12(3), 549-575. https://doi.org/10.1007/s11482-016-9476-5.

Yuliandi, \& Tahir, R. (2019). Work discipline, competence, empowerment, job satisfaction, and employee performance. International Journal of Recent Technology and Engineering, 8(3), 7209-7215. https://doi.org/10.35940/ijrte.C6221.098319. 